\title{
Cav1.2 and Cav1.3 L-type calcium channels regulate the resting membrane potential but not the expression of calcium transporters in differentiated PC12 cells
}

\author{
Lucia Lichvárová and Lubica Lacinová \\ Institute of Molecular Physiology and Genetics, Centre of Excellence for Cardiovascular Research, Slovak Academy \\ of Sciences, Bratislava, Slovak Republic
}

\begin{abstract}
PC12 cells differentiated under the influence of the neuronal growth factor (NGF) serve as a model of both sympathetic neurons and chromaffin cells. NGF-induced differentiation critically depends on elevated intracellular calcium concentration. Main pathway for $\mathrm{Ca}^{2+}$ entry in excitable cells is represented by voltage-dependent calcium channels including L-type calcium channels (LTCC). We investigated role of $\mathrm{Ca}_{\mathrm{V}} 1.2$ and $\mathrm{Ca}_{\mathrm{V}} 1.3$ LTCC subtypes in NGF-differentiated PC12 cells. The expression of LTCC subtypes was downregulated by transfection of NGF-differentiated PC12 cells with siRNA for either CACNA1C or CACNA1D gene. Efficiency of gene silencing was verified by RT-PCR and by functional essay. The dominant LTCC subtype in PC12 cells was Ca 1.2 . Downregulation of either LTCC significantly hyperpolarized the resting membrane potential. Expression of mRNA for intracellular calcium transporters inositol trisphosphate receptor type 1, 2 and 3, ryanodine receptor type 1 and 2 and sarco/endoplasmic reticulum $\mathrm{Ca}^{2+}$ ATPase type 2 as well as plasma membrane transporters $\mathrm{Na}^{+}-\mathrm{Ca}^{2+}$ exchanger type 1 and 2 was not altered in the absence of either LTCC subtype. In conclusion, $\mathrm{Ca}^{2+}$ influx through $\mathrm{Ca}_{\mathrm{V}} 1.2$ or to $\mathrm{Ca}_{\mathrm{V}} 1.3$ channel subtypes contributes to maintenance of the resting membrane potentials of NGF-differentiated PC12 cells but is not required for regulation of expression of genes for calcium-transporting proteins.
\end{abstract}

Key words: PC12 cells $-\mathrm{Ca}_{\mathrm{V}} 1.2-\mathrm{Ca}_{\mathrm{V}} 1.3-\mathrm{IP}_{3}$ receptor - Ryanodine receptor $-\mathrm{Na}^{+}-\mathrm{Ca}^{2+}{ }_{-}$ exchanger - Resting membrane potential

\section{Introduction}

PC12 cell line was established by Greene and Tischler (1976) from a rat adrenal pheochromocytoma. These cells are commonly used as a model of neurodifferentiation and are considered as a sympathetic neuron-like and/or chromaffin cell-like. Differentiation of PC12 cells can be activated by multiple external factors including neuronal growth factor (NGF). $\mathrm{Ca}^{2+}$ entry from extracellular space was required for differentiation and significant upregulation of L-type calcium current accompanied it (Lievano et al. 1994; Lichvarova et al. 2012).

Regulation of calcium homeostasis in NGF-differentiated PC12 cells is more close to that of sympathetic neurons

Correspondence to: Lubica Lacinová, Institute of Molecular Physiology and Genetics, Centre of Excellence for Cardiovascular Research, Slovak Academy of Sciences, Bratislava, Slovak Republic E-mail: lubica.lacinova@savba.sk than that of chromaffin cells (Duman et al. 2008). Similar to chromaffin cells (Morgado-Valle et al. 1998), NGF upregulated the expression of L-type calcium channels (LTCC) in sympathetic neurons, as well (Lei et al. 1997; Ford et al. 2008). Calcium influx through LTCC significantly contributes to activity-dependent gene transcription in both sympathetic and CNS neurons in spite that these channels contribute only a lesser part of total calcium current (Morgan and Curran 1986; Bito et al. 1996; Zhao et al. 2007). It is tempting to expect that calcium influx through LTCC plays a role in neurodifferentiation of PC12 cells. Indeed, an L-type but not N-type calcium current was necessary for Numb-mediated neurite outgrowth in PC12 cells (Lu et al. 2009). On the other hand, mid-term (Lu et al. 2009) or long-term (Lichvarova et al. 2012) inhibition of LTCC by dihydropyridines did not affect NGF-induced neurite outgrowth in PC12 cells, which is one of hallmarks of their neurodifferentiation. 
Calcium homeostasis in PC12 cells is regulated by a crosstalk of multiple calcium channels and calcium transporters in both plasma membrane and sarco/endoplasmic reticulum membrane (Duman et al. 2008). LTCC directly control gene transcription in excitable cells (Dolmetsch et al. 2001; Gomez-Ospina et al. 2006) and are functionally and transcriptionally coupled to ryanodine receptor (RyR) type 2 in rat hippocampus (Kim et al. 2007) and to inositol-1,4,5-trisphosphate receptors $\left(\mathrm{IP}_{3} \mathrm{R}\right)$ in mouse hippocampal neurons (Kato et al. 2012) and in vascular smooth muscle (Abou-Saleh et al. 2013). It is possible that altered expression level of other calcium transporting proteins in differentiated PC12 cells may compensate lack of calcium influx via LTCC.

The aim of our work was to analyze contribution of $\mathrm{Ca}_{\mathrm{V}} 1.2$ and $\mathrm{Ca}_{\mathrm{V}} 1.3$ subtypes to total LTCC in NGFdifferentiated PC12 cells and to elucidate whether activity of these channels is required for expression of calcium transporters in both plasma membrane $\left(\mathrm{Na}^{+}-\mathrm{Ca}^{2+} \mathrm{ex}^{-}\right.$ changer, NCX1 and NCX2) and sarco/endoplasmic reticulum membrane (RyR1 and RyR2, IP ${ }_{3} \mathrm{R} 1-3$, and sarco/ endoplasmic reticulum calcium transport ATPase - SERCA2). Expression of both LTCC subtypes was suppressed by siRNA and absence of functional channel protein was confirmed by measuring corresponding calcium current by means of patch clamp.

\section{Material and Methods}

\section{Cell maintenance and transfection}

PC12 cell line was purchased from DSMZ (Deutsche Sammlung von Mikroorganismen und Zellkulturen GmbH, Braunschweig, Germany) and grown in DMEM with Lglutamin, 20\% fetal bovine serum and $100 \mathrm{U} / \mathrm{ml}$ Penicillinstreptomycin in an atmosphere of $5 \% \mathrm{CO}_{2}$ and $95 \%$ air at $37^{\circ} \mathrm{C}$. Cell differentiation was initiated at Day 0 by supplementing the culture medium with $50 \mathrm{ng} / \mathrm{ml}$ of NGF. At the Day 9 of the NGF treatment cells were assigned into four groups. First group was cultured with NGF only for further 48 hours (control). For cell transfection nanoparticle siRNA Transfection System N-TER ${ }^{\mathrm{TM}}$ (Sigma-Aldrich Slovakia) was used. Second control group was treated by transfection reagent N-TER only to exclude possible effect of this reagent itself (N-TER). Third control group was transfected with a commercially available MISSION ${ }^{\circledR}$ siRNA Universal Negative Control (siRNA - UNC; Sigma-Aldrich Slovakia) (NC). Fourth group was transfected with a mixture of three commercially available MISSION ${ }^{\circledR}$ siRNAs (Sigma-Aldrich Slovakia) specific either for the CACNA1C gene encoding for the $\mathrm{Ca}_{\mathrm{V}} 1.2$ channel (CACNA1CsiRNA) or for the CACNA1D gene encoding for the $\mathrm{Ca}_{\mathrm{V}} 1.3$ channel (CAC-
NA1DsiRNA). For electrophysiological experiments siRNAs were fluorescently labeled with 6-Carboxyfluorescein (6-FAM) to allow visual identification of transfected cells. Total concentration of siRNA was $80 \mathrm{nM}$ in all cases.

\section{Molecular analysis}

Expression of genes encoding the $\alpha_{1}$ subunits of the $\mathrm{Ca}_{V} 1.2$ channel (CACNA1C gene), Ca 1.3 channel (CACNA1D gene) and calcium transporters NCX1, NCX2, $\mathrm{IP}_{3} \mathrm{R} 1$, $\mathrm{IP}_{3} \mathrm{R} 2, \mathrm{IP}_{3} \mathrm{R} 3, \mathrm{RyR} 1, \mathrm{RyR} 2$ and SERCA2 was evaluated by RT-PCR analysis from total cell lysates of PC12 cells harvested 48 hours after transfection as described previously (Lichvarova et al. 2012). Briefly, total RNA was isolated by TRI Reagent (Sigma-Aldrich Slovakia), homogenized for 5 minutes at a room temperature and extracted by chloroform/ isopropanol precipitation (SERVA GmbH Germany). After centrifugation RNA pellet was washed with $70 \%$ ethanol and precipitated in $96 \%$ ethanol (SERVA GmbH Germany) at $-20^{\circ} \mathrm{C}$ overnight. Samples were stored for longer time at $-70^{\circ} \mathrm{C}$. Reverse transcription was performed using $1.5 \mu \mathrm{g}$ of total RNAs and Ready-To-Go You-Prime First-Strand Beads (GE Healthcare UK) with Random Hexamer Primer (Fermentas Germany). GAPDH was used as a housekeeper gene for semi-quantitative evaluation of PCR products. All PCR products were analyzed on $2 \%$ agarose gels.

\section{Electrophysiological experiments}

HEKA-10 patch clamp amplifier (HEKA Electronic, Lambrecht, Germany) was used for whole-cell patch clamp experiments. The extracellular solution contained (in $\mathrm{mM}$ ): $\mathrm{NaCl} 130, \mathrm{KCl} 4, \mathrm{BaCl}_{2} 20, \mathrm{MgCl}_{2}$ 1, HEPES 10, glucose 10, pH 7.4 (with $\mathrm{NaOH}$ ). The intracellular solution contained (in mM): $\mathrm{CsCl}$ 100, EGTA 14, $\mathrm{NaCl} \mathrm{10,}$ TEA-Cl 20, Mg-ATP 5, Na-GTP 0.3, HEPES 20, pH 7.4 (with $\mathrm{CsOH}$ ). For measurement of a resting membrane potential (RMP) bath solution mimicked the ionic composition of culture media and contained (in $\mathrm{mM}$ ): $\mathrm{NaCl}$ 109.51, $\mathrm{KCl} 5.36$, HEPES 10, $\mathrm{CaCl}_{2} 1.36, \mathrm{MgSO}_{4}$ 0.81, $\mathrm{NaHCO}_{3} 44.04, \mathrm{NaH}_{2} \mathrm{PO}_{4}$ 0.91, D-glucose 24.98, pH 7.4 $(\mathrm{NaOH})$. Pipette solution contained (in mM): MgATP 3, HEPES 10, EGTA 10, K-gluconate 130, KCl 20, NaGTP $0.4, \mathrm{pH} 7.4(\mathrm{KOH})$. RMP was measured using perforated patch clamp with $50 \mu \mathrm{g} / \mathrm{ml}$ amphotericin B.

Osmolarity of experimental solutions was measured with Osmomat 030 (Gonotec GmbH, Germany). The osmolarity of pipette solutions was approximately $300 \mathrm{mOsm}$. The osmolarity of bath solution was adjusted by varying glucose concentration to a value by 3-4 mOsm lower, then the osmolarity of pipette solution.

Expression of L-type calcium channel proteins was assessed by measuring of inward calcium currents and inhibiting part 
carried by LTCC by $1 \mu \mathrm{M}$ of isradipine (Lichvarova et al. 2012). Stock solution (10 mM) of isradipine (Sigma-Aldrich Slovakia) was prepared in ethanol, stored at $-20^{\circ} \mathrm{C}$ and dissolved to a final concentration of $1 \mu \mathrm{M}$ in a bath solution prior to the experiment. Extracellular solutions were exchanged by a gravity-driven flow system with manually controlled valves. Patch pipettes were manufactured from borosilicate glass (Sutter Instrument, Novato, CA) with input resistance ranging from 2.0 to $2.5 \mathrm{M} \Omega$. The cell capacitance ranged between 20 and $80 \mathrm{pF}$. Capacity transient and series resistance were compensated up to $70 \%$. Residual linear leak current was subtracted by built-in procedure of the EPC 10 amplifier.

Data are presented as a mean \pm S.E.M. Values measured at individual days were compared by one-way ANOVA with Tukey post-test and $p<0.05$ was considered significant.

A
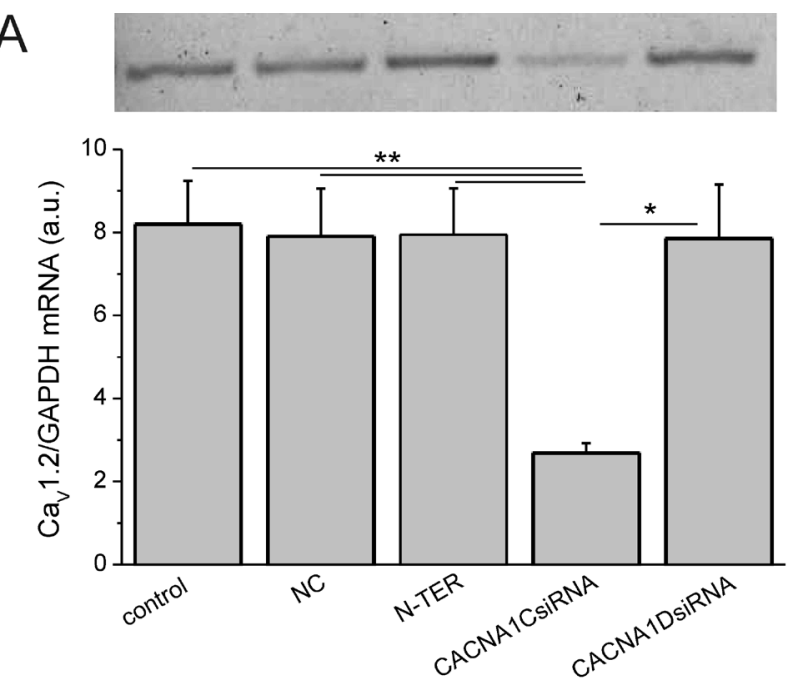

C

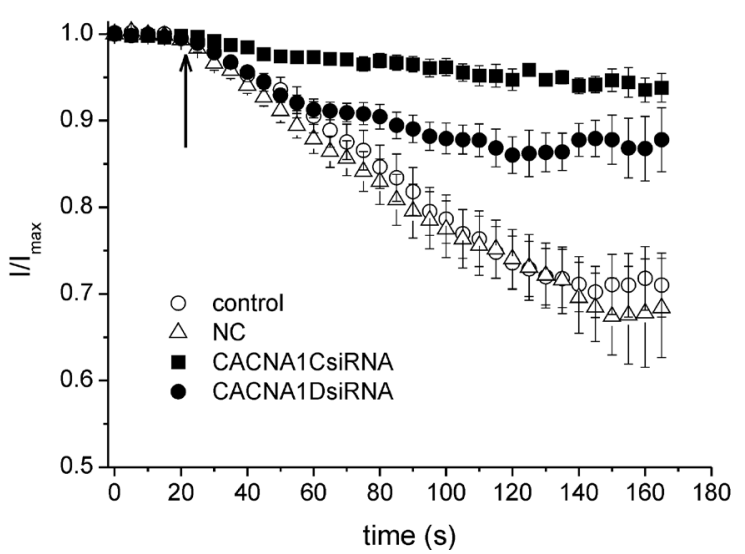

\section{Results}

Previously, we have shown that L-type calcium current is upregulated in PC12 cells during differentiation activated by NGF and that this process reaches plateau after 8 days of NGF treatment (Lichvarova et al. 2012). Therefore the transfection was scheduled at the Day 9. Effects of transfection were evaluated after 48 hours. As a first, we evaluated efficiency of siRNA-downregulation of the expression of $\mathrm{Ca}_{\mathrm{V}} 1.2$ (CACNA1C gene) and Ca 1.3 (CACNA1D gene) channels. In PC12 cell transfected with CACNA1C-specific siRNA relative mRNA level for the CACNA1C gene decreased significantly while in cells transfected with CACNA1D-specific siRNA the CACNA1C gene was not affected (Fig. 1A). Transfection reagent itself (N-TER) or transfection
B
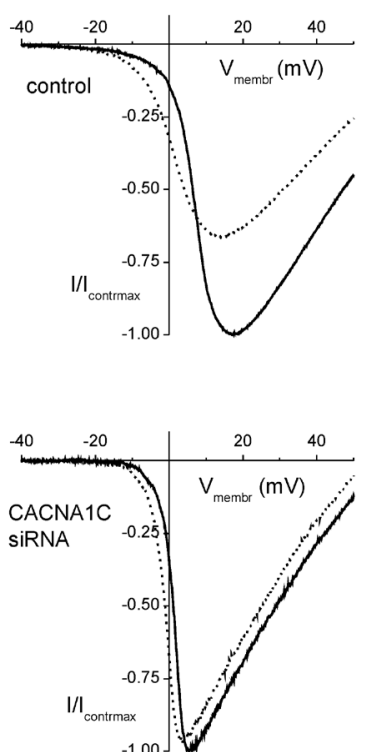
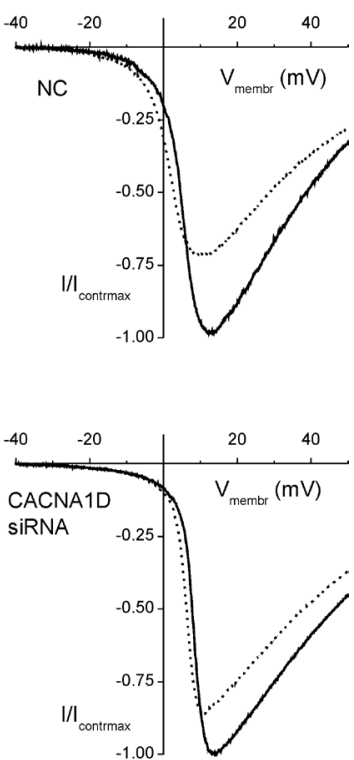

Figure 1. Concentration of mRNA for CACNA1C gene (A) was evaluated relative to the concentration of mRNA for the housekeeping GAPDH gene. Data represent an average from 5 independent transfections. An example of an electrophoresis gel showing the bands corresponding to the amplified fragment of CACNA1CmRNA is in the inset. Data are presented as a mean \pm SEM. ${ }^{\star} p<0.05 ;{ }^{* *} p<$ 0.01 . Examples of I-V relations for calcium currents activated by a voltage ramp from a holding potential of $-80 \mathrm{mV}$ to $+80 \mathrm{mV}$ with a speed of $0.8 \mathrm{~V} / \mathrm{s}(\mathbf{B})$. Only a part of recorded current trace between $-40 \mathrm{mV}$ and $+50 \mathrm{mV}$ is shown. Solid line represents calcium current recorded under in the control bath solution and dashed line the current recorded in the presence of $1 \mu \mathrm{M}$ isradipine. Averaged time courses of peak I-V amplitudes expressed as a fraction of maximal calcium current measured under the control conditions are shown in (C). Moment of application of $1 \mu \mathrm{M}$ isradipine is marked by an arrow. Cells originated from 5 independent transfections. Data are presented as a mean \pm SEM. In all panels control denotes group of cells cultured in the presence of NGF without any other treatment. Other groups were transfected with transfection reagent only (N-TER), with scrambled siRNAs (NC), with a mixture of three siRNAs specific for CACNA1C gene (CACNA1CsiRNA) and with a mixture of three siRNAs specific for CACNA1D gene (CACNA1DsiRNA). 


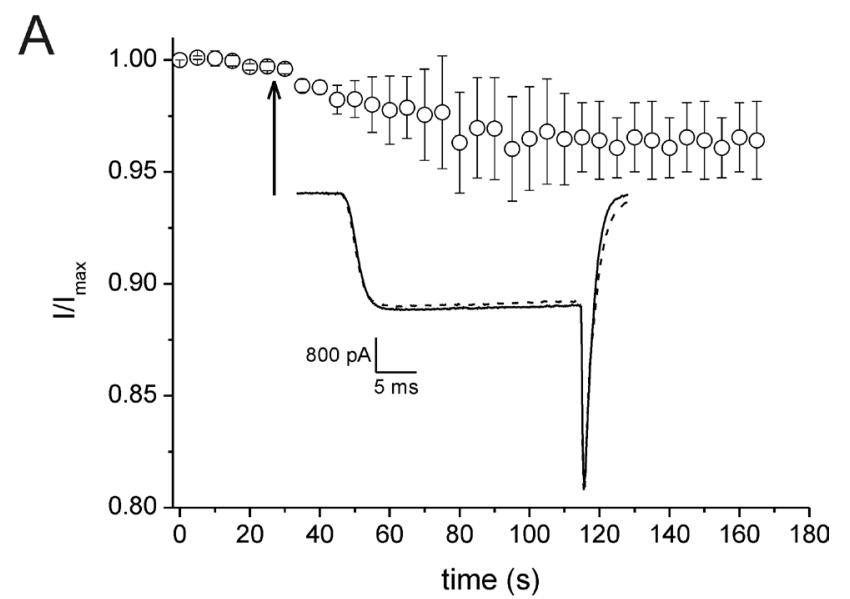

B

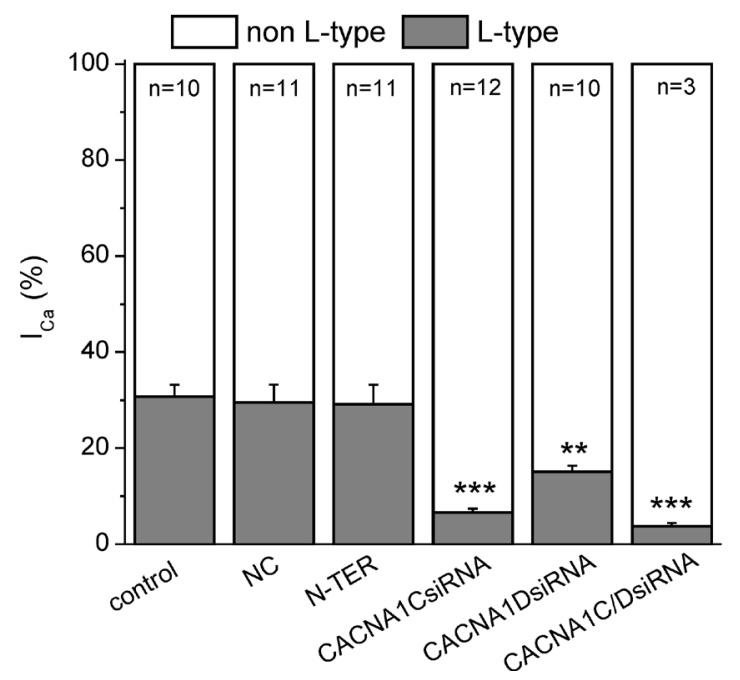

Figure 2. A. Averaged time courses of current amplitudes expressed as a fraction of maximal calcium current measured under the control conditions. Moment of application of $1 \mu \mathrm{M}$ isradipine is marked by an arrow. Current was activated by a series of depolarizing pulses from $-80 \mathrm{mV}$ to $+20 \mathrm{mV}$. Cells were transfected with siRNAs for both CACNA1C and CACNA1D genes. Example of original current recordings measured under the control conditions (solid line) and in the presence of isradipine (dashed line) is shown in the inset. B. Average amplitude of L-type calcium current expressed in percentage of total calcium current was calculated from a current blocked by isradipine in experiments documented in the Figure 1C and 1A. Number of cells measured in each group is marked in the graph. Except for the last column cells originated from 5 independent transfections. Data are presented as a mean \pm SEM. ${ }^{* *} p<0.01 ;{ }^{* *} p<0.001$ versus all control groups. Control denotes group of cells cultured in the presence of NGF without any other treatment. Other groups were transfected with transfection reagent only (N-TER), with scrambled siRNAs (NC), with a mixture of three siRNAs specific for CACNA1C gene (CACNA1CsiRNA), with a mixture of three siRNAs specific for CACNA1D gene (CACNA1DsiRNA) and with a mixture of six siRNAs specific for either CACNA1C (three) or for CACNA1D (three) genes (CACNA1C/ DsiRNA). with scrambled siRNAs (NC) did not alter relative mRNA level for the CACNA1C gene (Fig. 1A). To detect mRNA level for the CACNA1D gene use of nested RT-PCR was necessary (Michna et al. 2003), therefore we could not evaluate relative mRNA concentration for this gene and we relied solely on the functional test for protein expression.

As the amplitude of L-type calcium current is directly proportional to the number of functional channels expressed in the cell membrane, it was used as a measure for quantification of expression of functional channel proteins (Hille 2001). To minimize rundown, calcium current was activated by voltage ramps. $1 \mu \mathrm{M}$ isradipine is capable completely inhibit L-type calcium current in PC12 cells (Lichvarova et al. 2012). Relative contribution of blocked, i.e., an L-type, current to the total current was calculated from amplitudes of ramp currents recorded in the control solution and in equilibrium with $1 \mu \mathrm{M}$ isradipine (Fig. 1B, C). Currents recorded in control, N-TER and NC groups did not differ. Further, we tested whether transfection with siRNAs for both CACNA1C and CACNA1D genes will fully suppress LTCC. For this experiment we have decreased concentration of siRNA for individual genes to $40 \mathrm{nM}$ so that total concentration of all siRNAs was again $80 \mathrm{nM}$. Higher concentration may have cytotoxic effect. In these cells (Fig. 2A) LTCC represented only $3.7 \pm 0.6 \%$ of total calcium current, i.e., efficiency of gene silencing was $88 \%$. As in this experiment concentration of siRNAs for individual CACNA1C and CACNA1D genes was lowered, actual efficiency of individual gene silencing may be even higher.

Transfection with siRNA specific for either $\mathrm{Ca}_{V} 1.2$ or $\mathrm{Ca}_{\mathrm{V}} 1.3$ channel significantly suppressed amplitude of L-type calcium current (Fig. 2B). It was apparent that a dominant isoform of L-type calcium channel in PC12 cells is $\mathrm{Ca}_{\mathrm{V}} 1.2$ channel. Density of total calcium current was not affected by transfection with either siRNAs (Fig. 2B and Table 1). Silencing of the gene for the $\mathrm{Ca}_{\mathrm{V}} 1.2$ channel caused a mild decrease of average total current amplitude, nevertheless, this decrease was not significant (Table 1). Cell capacity, which is a measure of a cell size, was not altered by a transfection with CACNA1CsiRNA or CACNA1DsiRNA (Figure 3A). RMP was significantly hyperpolarized when the expression either of both channels was downregulated (Figure 3B). Hyperpolarization was slightly more prominent in CACNA1CsiRNA group. To test whether block of LTCC by $1 \mu \mathrm{M}$ isradipine can mimick this effect we continuously monitored RMP and applied the drug to a PC12 cells from all three control groups. Example of such experiment is in the Figure 3C (a cell from a control group). However, we only observed minor depolarization of RMP by about $1 \mathrm{mV}$. This effect was not statistically significant.

PC12 cells exposed for 11 days to NGF express mRNA for surface membrane calcium transporters NCX1 and NCX2 as well as for intracellular ion channels and transporters $\mathrm{IP}_{3} \mathrm{R} 1$, $\mathrm{IP}_{3} \mathrm{R} 2, \mathrm{IP}_{3} \mathrm{R} 3$, RyR1, RyR2 and SERCA2 (Fig. 4). Relative 
Table 1. Densities of total, L-type, and non-L-type calcium current

\begin{tabular}{lccc}
\hline & NC & CACNA1CsiRNA & CACNA1DsiRNA \\
\hline $\mathrm{I}_{\mathrm{Ca}-\mathrm{L}}(\mathrm{pA} / \mathrm{pF})$ & $-10.6 \pm 3.2(11)$ & $-1.8 \pm 0.5(12)^{\star}$ & $-6.6 \pm 1.8(10)$ \\
$\mathrm{I}_{\mathrm{Ca}-n o n-\mathrm{L}}(\mathrm{pA} / \mathrm{pF})$ & $-26.9 \pm 4.6(11)$ & $-31.0 \pm 5.7(12)$ & $-32.1 \pm 4.2(10)$ \\
$\mathrm{I}_{\mathrm{Ca}}(\mathrm{pA} / \mathrm{pF})$ & $-36.7 \pm 7.0(11)$ & $-33.4 \pm 6.0(12)$ & $-38.7 \pm 5.6(10)$ \\
\hline
\end{tabular}

Average current density was measured in each of three control groups and in cells transfected with siRNAs for either $\mathrm{Ca}_{V} 1.2$ or $\mathrm{Ca}_{V} 1.3$ channel. L-type calcium current density was identified as a density of current blocked by $1 \mu \mathrm{M}$ isradipine and non-L-type calcium current density was established as a density of current remaining in the presence of $1 \mu \mathrm{M}$ isradipine. Values obtained from control groups (control, N-TER, NC) were not significantly different. For a sake of clarity only NC group is listed in the table. $\mathrm{I}_{\mathrm{Ca}}, \mathrm{I}_{\mathrm{Ca}-\mathrm{L}}$ and $\mathrm{I}_{\mathrm{Ca}-n o n-\mathrm{L}}$ represent total calcium current, L-type calcium current, and non-L-type calcium current density, respectively. Number of cells tested is indicated in brackets. ${ }^{*} p<0.05 v s$. NC.

mRNA concentration for none of those was altered when cells were treated for 48 hours with transfection reagent $\mathrm{N}$ TER or transfected with scrambled siRNA (NC). For a sake of clarity, only NC group was included into graphs of Fig. 4. Downregulation of the expression of $\mathrm{Ca}_{\mathrm{V}} 1.2$ channel did not alter expression level of none of these channels and transporters (Fig. 4). Most prominent effects of CACNA1D downregulation were enhancement of mRNA level for $\mathrm{IP}_{3} \mathrm{R} 2$ and suppression of mRNA level for NCX1, nevertheless, neither of them was significant (Fig. 4).

\section{Discussion}

PC12 cells are commonly used as a model of sympathetic neurons and/or chromaffin cells. Duman and collabora-
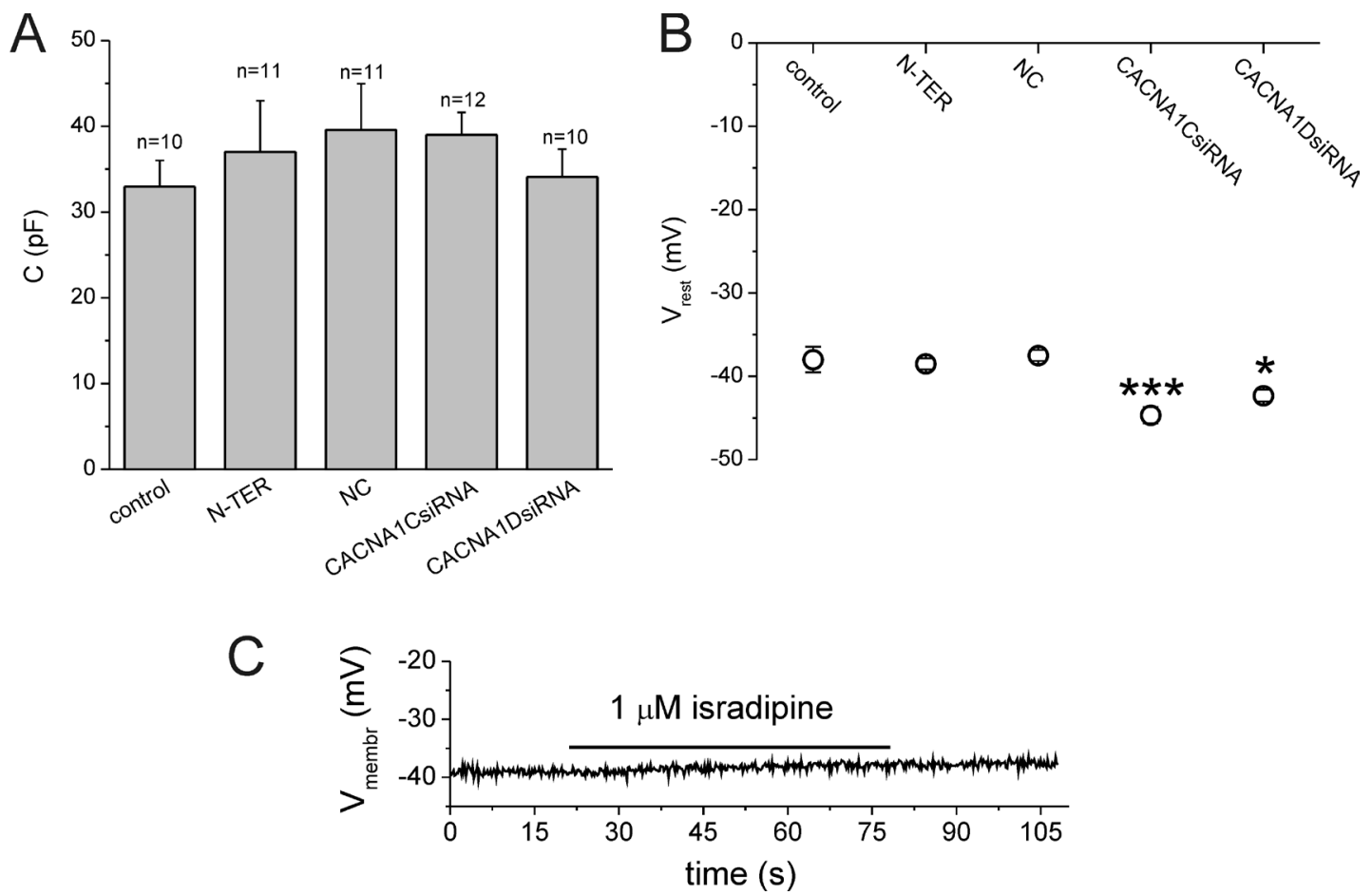

Figure 3. Average cell capacity (A) and resting membrane potential (B) measured from cells cultured in the presence of NGF without any other treatment (control), cells transfected with transfection reagent only (N-TER), with scrambled siRNAs (NC), with a mixture of three siRNAs specific for CACNA1C gene (CACNA1CsiRNA) and with a mixture of three siRNAs specific for CACNA1D gene (CACNA1DsiRNA). Number of cells tested in each group is marked in the panel A. In the panel B number of cell is each group was 6 . Data are presented as a mean \pm SEM. ${ }^{*} p<0.05 ;{ }^{* *} p<0.01$ versus all control groups. Representative example of continuous resting membrane potential $\left(\mathrm{V}_{\text {membr }}\right)$ recording from a control cell is shown in the panel $\mathrm{C}$. Duration of application of $1 \mu \mathrm{M}$ isradipine is marked. $\mathrm{C}$, average cell capacity; $\mathrm{V}_{\text {rest }}$, resting membrane potential. 
tors (Duman et al. 2008) analyzed calcium transport in PC12 cells mediated by transporters in plasma membrane (NCX) and in sarco/endoplasmic reticulum (SERCA). They concluded that mode of action of calcium transporters in NGF-differentiated PC12 cells resembles more closely that of sympathetic neurons (Duman et al. 2008). Our work was concentrated on the role of L-type calcium channels in the same cell model.

Voltage dependent calcium channels play important role in physiology of both chromaffin cells and sympathetic

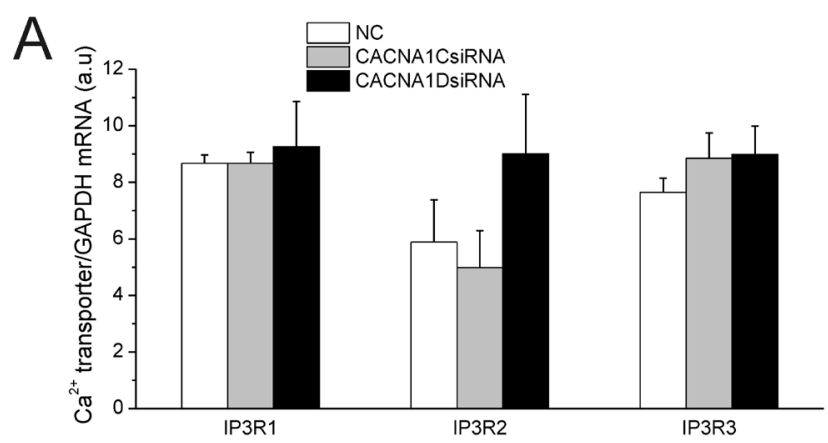

$\mathrm{B}$
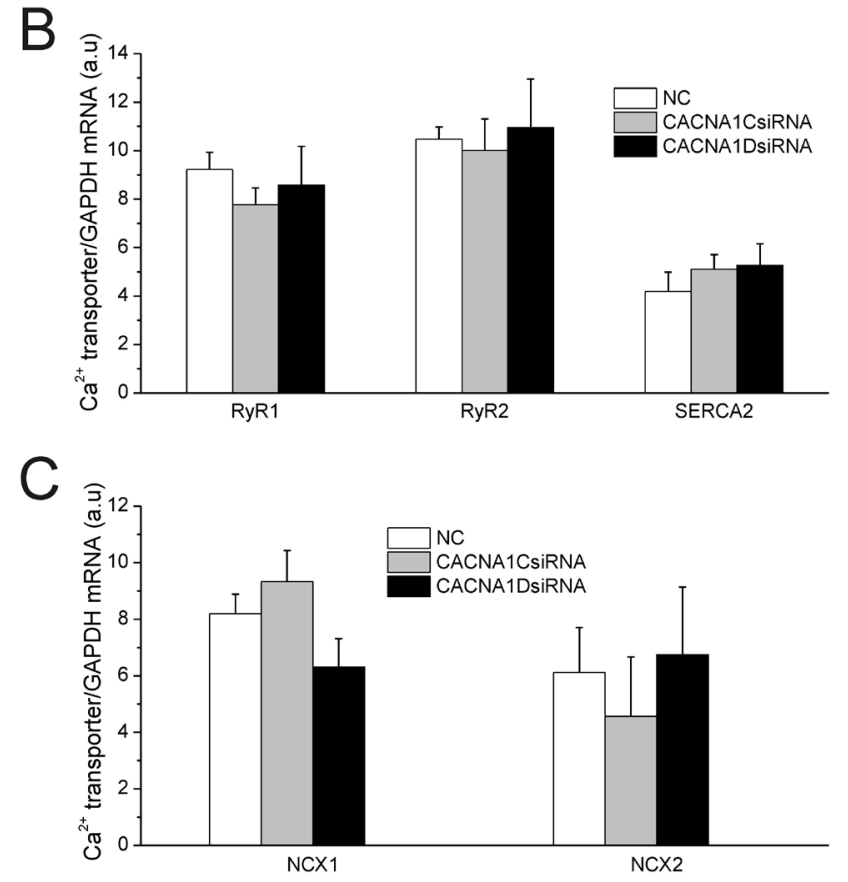

Figure 4. Concentration of mRNA for genes encoding $\mathrm{IP}_{3} \mathrm{R}$ type 1 , 2 and 3 (A); RyR type 1 and 2, SERCA type 2 (B) and NCX type 1 and $2(\mathbf{C})$ was evaluated relative to the concentration of mRNA for the housekeeping GAPDH gene. Cells were transfected with scrambled siRNAs (NC), with a mixture of three siRNAs specific for CACNA1C gene (CACNA1CsiRNA) and with a mixture of three siRNAs specific for CACNA1D gene (CACNA1DsiRNA). Data are presented as a mean \pm SEM and represent an average from 5 independent transfections. neurons. PC12 cells cultured in presence of NGF exhibit significant LTCC activity (Liu et al. 1996; Duman et al. 2008; Lichvarova et al. 2012) supported by both $\mathrm{Ca}_{V} 1.2$ and $\mathrm{Ca}_{V} 1.3$ channel subtypes (Colston et al. 1998). Contribution of these channel subtypes to total LTCC cannot be evaluated by pharmacological means as no selective channel blocker is available. Therefore, we have used siRNA technique to downregulate separately expression of these proteins. Previously, we have shown that after 8 days of NGF exposure differentiation of PC12 cells manifested by neurite outgrowth, increased expression of LTCC, and percentage of differentiated cells reaches its plateau (Lichvarova et al. 2012). Therefore Day 9 was chosen for transfection of cells with a mixture of three specific siRNAs either for the CACNA1C gene or for the CACNA1D gene. Suppression of the expression of CACNA1C and/or CACNA1D genes did lead to suppression of the expression of functional channel proteins. Consistent with previous works on NGF-differentiated PC12 cells (McCullough et al. 1998; Lichvarova et al. 2012), Cav1.2 and Cav1.3 channels were together responsible for approximately $30 \%$ of total voltage-dependent calcium current. This is somehow less than in rat or mouse chromaffin cells in which LTCC carry about $40-50 \%$ of total calcium current (Marcantoni et al. 2008, 2010; Mahapatra et al. 2012; de Pascual et al. 2013). On the other hand, it is much more than in sympathetic neurons, where LTCC contribute only a minor part (8-16\%) of total calcium current (Zhao et al. 2007; Hernandez-Ochoa et al. 2009; Vivas et al. 2014). Furthermore, in adult rat sympathetic neurons exposure to NGF reduced LTCC from 16 to $6 \%$ of the total calcium current (Vivas et al. 2014) while in chromaffin cells NGF-treatment increased calcium current amplitude (Morgado-Valle et al. 1998).

At least $75 \%$ of L-type calcium current in PC12 cells was carried by the $\mathrm{Ca}_{\mathrm{V}} 1.2$ channel. Contribution of channel subtypes to total LTCC in chromaffin cells was analyzed in Ca 1 1.3-knockout mouse (Marcantoni et al. 2010; Mahapatra et al. 2012). In this model both channel subtypes contributed equally to the total LTCC (Marcantoni et al. 2010; Mahapatra et al. 2011, 2012). While both channel subtypes are equally important for LTCC regulation by protein kineses C and G (Mahapatra et al. 2012), Ca 1.3 channel was more important with regard to pacemaking in mouse chromaffin cells than the $\mathrm{Ca}_{\mathrm{V}} 1.2$ channel (Marcantoni et al. 2010; Mahapatra et al. 2011).

Absence of either $\mathrm{Ca}_{\mathrm{V}} 1.2$ or $\mathrm{Ca}_{\mathrm{V}} 1.3$ channel did not result in decrease in cell capacity suggesting that no recess of neuronal processes took place and therefore no calcium influx through LTCC was necessary for neurite maintenance. This observation is in line with previous finding that chronic inhibition of LTCC by dihydropyridines lasting 4 days (Lu et al. 2009) or 9 days (Lichvarova et al. 2012) did not prevent NGF-dependent neurite outgrowth (Lu et al. 2009; Lichvarova et al. 2012). 
In nondifferentiated PC12 cells RMP measured by a conventional whole cell patch clamp was found to be $-27.5 \mathrm{mV}$ (Zhang et al. 2012), and $-37 \pm 1 \mathrm{mV}$ (Zhu et al. 1996). Taylor and collaborators (Taylor et al. 2000) measured RMP in nondifferentiated PC12 cells using perforated patch clamp and reported a mean value of $-35 \mathrm{mV}$. In PC1 2 cells differentiated by $100 \mathrm{ng} / \mathrm{ml}$ of NGF RMP measured by conventional wholecell patch clamp at the day 3 and at the day 12 was $-46 \pm$ $1.7 \mathrm{mV}$ and $-50 \pm 6.2 \mathrm{mV}$, respectively (Jeub et al. 2006). Rat chromaffin cells were reported to have RMP -60 mV (Akaike 1992) and $-62 \pm 3 \mathrm{mV}$ (Hollins and Ikeda 1996). RMP of rat sympathetic neurons was $-51.9 \pm 2.3 \mathrm{mV}$ (Doczi et al. 2008) and $-55.6 \pm 1.3 \mathrm{mV}$ (Lamas et al. 2009). RMP in control PC12 cells found in our experiments was close to $-40 \mathrm{mV}$. More depolarized value compared to that of Jeub (Jeub et al. 2006) may be caused by lower concentration of NGF which we used and by difference in composition of extracellular solution, which mimicked composition of culture medium in our experiments. Generally, RMP of PC12 cells is more close to that of sympathetic neurons.

Resting membrane potential was significantly hyperpolarized in cells with downregulated CACNA1C or CACNA1D genes, suggesting that LTCC do participate in its maintenance. The observation that when LTCC are expressed RMP is slightly depolarized supports our previous proposal that in PC12 cell cultured under standard conditions opening probability of these channels may be greater than zero and they may provide basal calcium influx (Lichvarova et al. 2012). Similarly, when cultured chromaffin cells, which have more negative RMP, were chronically depolarized by $\mathrm{KCl}$, reported were attributed to activity of LTCC (Benavides et al. 2007). Effects of LTCC on RMP are chronic, as the acute inhibition of LTCC by isradipine did not have immediate effect on RMP.

Various potassium channels contribute to RMP regulation in excitable cells. NGF-differentiated PC12 cell express predominantly delayed-rectifier type of potassium current (Rhie et al. 1999; Castillo et al. 2001; Kim et al. 2004) which may be carried through the $\mathrm{K}_{\mathrm{V}} 2.1$ channel (Sharma et al. 1993). Some authors reported also minor (Castillo et al. 2001) or moderate contribution of an A-type potassium current carried through the $\mathrm{K}_{\mathrm{V}} 3.4$ channel (Pannaccione et al. 2007). Additionally, presence of calcium-dependent BK channels (Shimazu et al. 2005) and SK channels (Janbein et al. 2014) in PC12 cells was demonstrated. These channels may mediate effect of LTCC on RMP.

In our experiments inward calcium current was detectable in control cells at voltages positive to $-30 \mathrm{mV}$. However, the actual concentration of $\mathrm{Ca}^{2+}$ in a culture medium is 1.36 $\mathrm{mM}$ while our experiments were done using $20 \mathrm{mM} \mathrm{Ba}^{2+}$ as a charge carrier. Such difference in concentration of divalent cations shifts the I-V relationship by approximately $20 \mathrm{mV}$ towards more depolarized potentials.
Total calcium current amplitude was not significantly changed when expression of $\mathrm{Ca}_{\mathrm{V}} 1.2$ or $\mathrm{Ca}_{\mathrm{V}} 1.3$ channels was downregulated, suggesting that non-L-type calcium channels, which in PC12 cells are represented mostly by $\mathrm{Ca}_{V} 2.1$ and $\mathrm{Ca}_{V} 2.2$ channels (Colston et al. 1998), partly compensated for decreased calcium influx through LTCC. This suggestion is supported also by observed moderate, but insignificant increase in non-L-type current density in both CACNA1CsiRNA and CACNA1DsiRNA cell groups.

It is well known that calcium influx regulates gene transcription in excitable cells. LTCC are necessary for gene transcription in neuronal cells (Lipscombe et al. 2004) including sympathetic neurons (Zhao et al. 2007). This was not the case in NGF-differentiated PC12 cells. No significant changes in expression of $\mathrm{mRNAs}$ for various calcium transporters were observed in the absence of either $\mathrm{Ca}_{\mathrm{V}} 1.2$ or $\mathrm{Ca}_{V} 1.3$ channels. Apparently, calcium influx through these channels is not necessary for regulation of gene expression of analyzed transporters.

In conclusion, we have shown that LTCC carry about 30\% of all inward calcium current in NGF-differentiated PC12 cells and that most of this current is carried through the $\mathrm{Ca}_{V} 1.2$ channel. LTCC contribute to regulation of resting membrane potential but not to regulation of transcription of genes encoding plasma and intracellular membrane calcium transporters. Relatively high proportion of LTCC in total calcium current and an enhancement of LTCC due to NGF treatment (Lichvarova et al. 2012) resemble properties of chromaffin cells. Relative proportion of $\mathrm{Ca}_{\mathrm{V}} 1.3$ channel in total LTCC in PC12 cells is smaller in PC12 cells than in chromaffin cells. Lack of contribution to the control of gene transcription contrasts the findings on sympathetic neurons. In regard to the role of LTCC in physiological regulations NGF-differentiated PC12 cells share some, but not all, features with chromaffin cells.

Acknowledgements. This work was supported by the Slovak Research and Development Agency under the contract No. APVV0212-10. Authors wish to thank Emilia Kocurova for an excellent technical assistance.

Conflict of interest. The authors declare no conflict of interest and no financial interest in the publication of this manuscript.

\section{References}

Abou-Saleh H., Pathan A. R., Daalis A., Hubrack S., AbouJassoum H., Al-Naeimi H., Rusch N. J., Machaca K. (2013): Inositol 1,4,5-trisphosphate (IP3) receptor up-regulation in hypertension is associated with sensitization of $\mathrm{Ca} 2+$ release and vascular smooth muscle contractility. J. Biol. Chem. 288, 32941-32951

http://dx.doi.org/10.1074/jbc.M113.496802 
Akaike A. (1992): Ionic mechanisms involved in muscarinic regulation of neuronal and paraneuronal activity. Jpn. J. Pharmacol. $\mathbf{5 8}, 83-93$ http://dx.doi.org/10.1254/jjp.58.83

Benavides A., Pastor D., Fradejas N., Tornero D., Calvo S. (2007): Differential regulation of calcium channel coding genes by prolonged depolarization. Neurochem. Int. 50, 395-403 http://dx.doi.org/10.1016/j.neuint.2006.09.013

Bito H., Deisseroth K., Tsien R. W. (1996): CREB phosphorylation and dephosphorylation: a $\mathrm{Ca}(2+)$ - and stimulus durationdependent switch for hippocampal gene expression. Cell 87, 1203-1214 http://dx.doi.org/10.1016/S0092-8674(00)81816-4

Castillo C., Carreno F., Villegas G. M., Villegas R. (2001): Ionic currents in PC12 cells differentiated into neuron-like cells by a cultured-sciatic nerve conditioned medium. Brain Res. 911, $181-192$ http://dx.doi.org/10.1016/S0006-8993(01)02683-X

Colston J. T., Valdes J. J., Chambers J. P. (1998): Ca2+ channel alpha 1-subunit transcripts are differentially expressed in rat pheochromocytoma (PC12) cells following nerve growth factor treatment. Int. J. Dev. Neurosci. 16, 379-389 http://dx.doi.org/10.1016/S0736-5748(98)00036-7

de Pascual R., Miranda-Ferreira R., Galvao K. M., Lameu C., Ulrich H., Smaili S. S., Jurkiewicz A., Garcia A. G., Gandia L. (2013): Lower density of L-type and higher density of P/Qtype of calcium channels in chromaffin cells of hypertensive, compared with normotensive rats. Eur. J. Pharmacol. 706, 25-35 http://dx.doi.org/10.1016/j.ejphar.2013.02.046

Doczi M. A., Morielli A. D., Damon D. H. (2008): Kv1.3 channels in postganglionic sympathetic neurons: expression, function, and modulation. Am. J. Physiol. Regul. Integr. Comp. Physiol. 295, R733-740 http://dx.doi.org/10.1152/ajpregu.00077.2008

Dolmetsch R. E., Pajvani U., Fife K., Spotts J. M., Greenberg M. E. (2001): Signaling to the nucleus by an L-type calcium channelcalmodulin complex through the MAP kinase pathway. Science 294, 333-339 http://dx.doi.org/10.1126/science.1063395

Duman J. G., Chen L., Hille B. (2008): Calcium transport mechanisms of PC12 cells. J. Gen. Physiol. 131, 307-323 http://dx.doi.org/10.1085/jgp.200709915

Ford C. P., Wong K. V., Lu V. B., Posse de Chaves E., Smith P. A. (2008): Differential neurotrophic regulation of sodium and calcium channels in an adult sympathetic neuron. J. Neurophysiol. 99, 1319-1332 http://dx.doi.org/10.1152/jn.00966.2007

Gomez-Ospina N., Tsuruta F., Barreto-Chang O., Hu L., Dolmetsch R. (2006): The C terminus of the L-type voltage-gated calcium channel $\mathrm{Ca}(\mathrm{V}) 1.2$ encodes a transcription factor. Cell 127, 591-606 http://dx.doi.org/10.1016/j.cell.2006.10.017

Greene L. A., Tischler A. S. (1976): Establishment of a noradrenergic clonal line of rat adrenal pheochromocytoma cells which respond to nerve growth factor. Proc. Natl. Acad. Sci. USA 73, 2424-2428 http://dx.doi.org/10.1073/pnas.73.7.2424
Hernandez-Ochoa E. O., Prosser B. L., Wright N. T., Contreras M., Weber D. J., Schneider M. F. (2009): Augmentation of Ca(v)1 channel current and action potential duration after uptake of S100A1 in sympathetic ganglion neurons. Am. J. Physiol., Cell Physiol. 297, C955-970 http://dx.doi.org/10.1152/ajpcell.00140.2009

Hille B. (2001): Ion Channels of Excitable Membranes. 3rd Edition. Sinauer Associates Inc., USA

Hollins B., Ikeda S. R. (1996): Inward currents underlying action potentials in rat adrenal chromaffin cells. J. Neurophysiol. 76, $1195-1211$

Janbein M., Quader M. A., Hoppner A. C., Gruner I., Wanker E., Walter S., Kuppers E., Grissmer S., Jager H. (2014): Evidence for the interaction of endophilin a 3 with endogenous Kca2.3 channels in PC12 cells. Cell. Physiol. Biochem. 34, 474-490 http://dx.doi.org/10.1159/000363016

Jeub M., Herbst M., Spauschus A., Fleischer H., Klockgether T., Wuellner U., Evert B. O. (2006): Potassium channel dysfunction and depolarized resting membrane potential in a cell model of SCA3. Exp. Neurol. 201, 182-192 http://dx.doi.org/10.1016/j.expneurol.2006.03.029

Kato H. K., Kassai H., Watabe A. M., Aiba A., Manabe T. (2012): Functional coupling of the metabotropic glutamate receptor, InsP3 receptor and L-type Ca2+ channel in mouse CA1 pyramidal cells. J. Physiol. 590, 3019-3034 http://dx.doi.org/10.1113/jphysiol.2012.232942

Kim S., Yun H. M., Baik J. H., Chung K. C., Nah S. Y., Rhim H. (2007): Functional interaction of neuronal Cav1.3 L-type calcium channel with ryanodine receptor type 2 in the rat hippocampus. J. Biol. Chem. 282, 32877-32889

http://dx.doi.org/10.1074/jbc.M701418200

Kim Y., Uhm D. Y., Shin J., Chung S. (2004): Modulation of delayed rectifier potassium channel by protein kinase $\mathrm{C}$ zeta-containing signaling complex in pheochromocytoma cells. Neuroscience 125, 359-368 http://dx.doi.org/10.1016/j.neuroscience.2003.08.004

Lamas J. A., Romero M., Reboreda A., Sanchez E., Ribeiro S. J. (2009): A riluzole- and valproate-sensitive persistent sodium current contributes to the resting membrane potential and increases the excitability of sympathetic neurones. Pflügers Arch. 458, 589-599 http://dx.doi.org/10.1007/s00424-009-0648-0

Lei S., Dryden W. F., Smith P. A. (1997): Regulation of N- and Ltype $\mathrm{Ca} 2+$ channels in adult frog sympathetic ganglion B cells by nerve growth factor in vitro and in vivo. J. Neurophysiol. 78, 3359-3370

Lievano A., Bolden A., Horn R. (1994): Calcium channels in excitable cells: divergent genotypic and phenotypic expression of alpha 1-subunits. Am. J. Physiol. 267, C411-424

Lichvarova L., Jaskova K., Lacinova L. (2012): NGF-induced neurite outgrowth in PC12 cells is independent of calcium entry through L-type calcium channels. Gen. Physiol. Biophys. 31, 473-478 http://dx.doi.org/10.4149/gpb_2012_054

Lipscombe D., Helton T. D., Xu W. F. (2004): L-type calcium channels: The low down. J. Neurophysiol. 92, 2633-2641 http://dx.doi.org/10.1152/jn.00486.2004 
Liu H., Felix R., Gurnett C. A., De Waard M., Witcher D. R., Campbell K. P. (1996): Expression and subunit interaction of voltage-dependent Ca2+ channels in PC12 cells. J. Neurosci. 16, 7557-7565

Lu C. B., Fu W., Xu X., Mattson M. P. (2009): Numb-mediated neurite outgrowth is isoform-dependent, and requires activation of voltage-dependent calcium channels. Neuroscience 161, 403-412 http://dx.doi.org/10.1016/j.neuroscience.2009.03.063

Mahapatra S., Marcantoni A., Vandael D. H., Striessnig J., Carbone E. (2011): Are $\mathrm{Ca}(\mathrm{v}) 1.3$ pacemaker channels in chromaffin cells? Possible bias from resting cell conditions and DHP blockers usage. Channels (Austin) 5, 219-224 http://dx.doi.org/10.4161/chan.5.3.15271

Mahapatra S., Calorio C., Vandael D. H., Marcantoni A., Carabelli V., Carbone E. (2012): Calcium channel types contributing to chromaffin cell excitability, exocytosis and endocytosis. Cell Calcium 51, 321-330 http://dx.doi.org/10.1016/j.ceca.2012.01.005

Marcantoni A., Carabelli V., Comunanza V., Hoddah H., Carbone E. (2008): Calcium channels in chromaffin cells: focus on $\mathrm{L}$ and T types. Acta Physiol. (Oxf). 192, 233-246 http://dx.doi.org/10.1111/j.1748-1716.2007.01815.x

Marcantoni A., Vandael D. H., Mahapatra S., Carabelli V., Sinnegger-Brauns M. J., Striessnig J., Carbone E. (2010): Loss of Cav1.3 channels reveals the critical role of L-type and BK channel coupling in pacemaking mouse adrenal chromaffin cells. J. Neurosci. 30, 491-504 http://dx.doi.org/10.1523/JNEUROSCI.4961-09.2010

McCullough L. A., Egan T. M., Westfall T. C. (1998): Neuropeptide $\mathrm{Y}$ receptors involved in calcium channel regulation in PC12 cells. Regul. Pept. 75-76, 101-107 http://dx.doi.org/10.1016/S0167-0115(98)00058-5

Michna M., Knirsch M., Hoda J. C., Muenkner S., Langer P., Platzer J., Striessnig J., Engel J. (2003): Cav1.3 (alpha1D) Ca2+ currents in neonatal outer hair cells of mice. J. Physiol. 553, 747-758 http://dx.doi.org/10.1113/jphysiol.2003.053256

Morgado-Valle C., Verdugo-Diaz L., Garcia D. E., Morales-Orozco C., Drucker-Colin R. (1998): The role of voltage-gated Ca2+ channels in neurite growth of cultured chromaffin cells induced by extremely low frequency (ELF) magnetic field stimulation. Cell Tissue Res. 291, 217-230 http://dx.doi.org/10.1007/s004410050992

Morgan J. I., Curran T. (1986): Role of ion flux in the control of c-fos expression. Nature 322, 552-555 http://dx.doi.org/10.1038/322552a0

Pannaccione A., Boscia F., Scorziello A., Adornetto A., Castaldo P., Sirabella R., Taglialatela M., Di Renzo G. F., Annunziato L.
(2007): Up-regulation and increased activity of KV3.4 channels and their accessory subunit MinK-related peptide 2 induced by amyloid peptide are involved in apoptotic neuronal death. Mol. Pharmacol. 72, 665-673 http://dx.doi.org/10.1124/mol.107.034868

Rhie D. J., Yi S. Y., Hahn S. J., Sim S. S., Jo Y. H., Kim M. S. (1999): Somatostatin potentiates voltage-dependent $\mathrm{K}+$ and $\mathrm{Ca} 2+$ channel expression induced by nerve growth factor in PC12 cells. Brain Res. Dev. Brain Res. 112, 267-274 http://dx.doi.org/10.1016/S0165-3806(98)00175-8

Sharma N., D'Arcangelo G., Kleinlaus A., Halegoua S., Trimmer J. S. (1993): Nerve growth factor regulates the abundance and distribution of $\mathrm{K}+$ channels in PC12 cells. J. Cell. Biol. 123, $1835-1843$ http://dx.doi.org/10.1083/jcb.123.6.1835

Shimazu K., Takeda K., Yu Z. X., Jiang H., Liu X. W., Nelson P. G., Guroff G. (2005): Multiple acute effects on the membrane potential of PC12 cells produced by nerve growth factor (NGF). J. Cell. Physiol. 203, 501-509 http://dx.doi.org/10.1002/jcp.20309

Taylor S. C., Green K. N., Carpenter E., Peers C. (2000): Protein kinase $\mathrm{C}$ evokes quantal catecholamine release from $\mathrm{PC} 12$ cells via activation of L-type Ca2+ channels. J. Biol. Chem. 275, 26786-26791

Vivas O., Kruse M., Hille B. (2014): Nerve growth factor sensitizes adult sympathetic neurons to the proinflammatory Peptide bradykinin. J. Neurosci. 34, 11959-11971 http://dx.doi.org/10.1523/JNEUROSCI.1536-14.2014

Zhang Y., Yang Y., Bi Y., Gong M., Jiang W., Wei X., Li T., Chen J. (2012): Mesenchymal stromal cell neuroprotection of hydrogen peroxide -challenged pheochromocytoma cells through reducing apoptosis and releasing cytokines. Cytotherapy 14, 954-966 http://dx.doi.org/10.3109/14653249.2012.688946

Zhao R., Liu L., Rittenhouse A. R. (2007): Ca2+ influx through both L- and N-type Ca2+ channels increases c-fos expression by electrical stimulation of sympathetic neurons. Eur. J. Neurosci. 25, 1127-1135 http://dx.doi.org/10.1111/j.1460-9568.2007.05359.x

Zhu W. H., Conforti L., Czyzyk-Krzeska M. F., Millhorn D. E. (1996): Membrane depolarization in PC-12 cells during hypoxia is regulated by an $\mathrm{O} 2$-sensitive $\mathrm{K}+$ current. Am. J. Physiol. 271, C658-665

Received: September 8, 2014

Final version accepted: November 14, 2014

First published online: February 12, 2015 